\title{
FACTORS AFFECTING AIR TRANSPORTATION
}

\author{
NINO KHUTCHUA \\ PhD student, \\ Georgian Technical University, Georgia \\ kozet1983@gmail.com
}

Abstract. The successful implementation of the concept of integration with Europe largely depends on the level of development of the transport infrastructure of our country. The integration process, first of all, implies political, socio-cultural, and economic communications, in the implementation of which the role of air transport is irreplaceable. Although the integration process is slow, nevertheless it continues and, following it, the number of citizens using air transport is growing. In this regard, it is interesting to know what the share of national airlines in terms of growth of this indicator is, i.e. what the share of participation of foreign and domestic companies in the total number of transported passengers is. At the same time, air carriers must take into account the environmental conditions that directly or indirectly affect the growth or reduction of passenger flows.

KEYWORDS: AIRLINE, AIR TRANSPORT, PASSENGER TRANSFERS, MACROECONOMIC INDICATORS, INFLATION, CONSUMER INDEX, INFLATION, TOURISM.

For citation: Khutchua, N., (2021). Factors Affecting Air Transportation. Globalization and Business, №11, 148-151. https://doi.org/10.35945/gb.2021.11.022

\section{PROBLEM STATEMENT}

I would like to remind you in a few sentences what legacy the civil aviation of Georgia inherited after the collapse of the Soviet Union. Morally and physically obsolete equipment, inefficient management, lack of investment sources, low passenger turnover, lack of work experience in a competitive environment.

The transition of the country to the rails of a market economy required a reorganization of the economic structure of air transport. Although obsolete equipment has been replaced by leased, relatively modern aircraft, airline management has made progress, airports have been built and upgraded to meet the increased demand of the passenger flow, but these measures have been insufficient to maintain a high share of Georgia (in terms of passenger service by airlines) in the civil aviation sector.

The open skies policy with Europe has become a difficult challenge for Georgian airlines as many European and nonEuropean air carriers have appeared on the Georgian air market, and they seriously compete with Georgian airlines for popular and highly demanded flights (mainly to Europe).

\section{MAIN TEXT}

The competitiveness of airlines in the air market is determined by technical and economic criteria and the most important of them are: volume of transportation, level of service, reasonable airfare, low operating costs, brand image, rapid response to changes in market conditions, effective functioning of management, timeliness and effectiveness of marketing activities, etc. According to Dumbadze (2009). There are qualitative and quantitative indicators that are used to assess the performance of air transport.

Quantitative indicators: volume of carriage of passengers, volume of transportation in tons-kilometers. The unit of measurement for calculating the airline transportations volume is the passenger. The volume is calculated by summing the number of passengers dispatched for a particular period.

Qualitative indicators show socio-technical-economic efficiency of air transport.

Technical indicators include transportation capacity, capacity of registration halls, aircraft and aircraft engines fleet and power, capacity of automation and mechanization means and provision of airlines.

Economic indicators - returns, transportation expenses and cost, profit, cost-efficiency, labor productivity.

Operating indicators - aircraft hourly productivity, annual flying hours, flight speed.

The structure of factors affecting the volume of passenger traffic was developed based on the analysis of the marketing environment of the airline.

In determining the factors affecting passenger transportation, special attention should be paid to the fact that airlines, when developing a strategic plan, often resort to forecasting the flow of passengers. Forecasting is based on an analysis of circumstances that can be considered in two subgroups.

Airline passenger flow generator:

1. Factors of direct or indirect impact

2. Subjective and objective factors 
The category of subjective factors includes a group of circumstances that are pre-selected and determined by the airline, such as airline management, marketing, supplier, intermediary, etc. Moreover, subjective circumstances are the tools at the airline's disposal to help it attract passengers and create a product. The category of objective factors includes a group of circumstances that the airline cannot influence, such as economic, demographic, climatic, sociocultural, etc. Both subjective and objective factors (indicators) directly or indirectly cause an increase or decrease in the number of passengers.

Civil aviation is a capital-intensive sector, so the intensity of its use is directly affected by indicators such as global, regional and national economic growth. Economic growth is one of the key concepts of macroeconomic theory. Economic growth refers to the quantitative growth of the economy, which is reflected in the change in the annual growth of gross (real) GDP (change in the wealth of the country's population and production capacity of the country) (Gegeshidze 2010). The Georgian economy as a whole is strongly affected by a complex of geopolitical risks. Russia, Turkey, Azerbaijan, Armenia, Ukraine, China and Eastern Europe are Georgia's main trading partners. The geopolitical risks of these countries and the slowdown in their economic growth negatively affect the Georgian economy. The tense geopolitical situation in the region and the high risk of destabilization has a direct negative impact on Georgia's economic relations, foreign trade and economic growth, in addition to the above mentioned, negatively affect expectations. The West continues to impose sanctions on Georgia's key trading partners amid a deteriorating political situation in the region. Reduced economic activity, tense geopolitical situation in the region, expectations of destabilization negatively affect foreign demand and economic growth.

In its turn, the aviation industry has a great impact on the economy in terms of its strong potential for creation of job and socio-economic connection. (Speed, flexibility, reliability, safety, affordable price). The growth rate of the country's economy ensures the accumulation of capital and creates the need to transport passengers and cargo, and as a result, this leads to increased demand for air transport.

The main target of the government policy of any country in the economy is to stimulate the economy in such a way that does not lead to raising the price level, i.e. growth of GDP without inflation when prices of individual goods are stable despite a large amount of money in circulation. This indicates that the productivity of the country's economic capacity has increased (Gegeshidze 2010). To assess the standard of living, economists use the macroeconomic indicator - GDP. When GDP grows, the standard of living increases over the long term, and due to cumulative growth spurts, even the slightest increase in the standard of living has the greatest impact on the mobility of the population. In the case of calculating the difficult percentage of GDP - "Rule of 72", (National Bank of Georgia ) the annual growth of $4.8 \%$ (which was observed in Georgia in 2017) will double the GDP in 15 years, 3\% in 24 years, and $8 \%$ in 9 years (National Statistics office of Georgia, 2020). The other indicators of national income are also used to assess economic well-being. For example, the Human Development Index. The determination of this indicator is based on three different indices:

- Average life expectancy;

- The level of education;

- Real average income.

However, most economists agree that GDP is best for estimating differences in living standards in different countries. The growing number of GDP per capita determines their availability and intensity of use for different types of transport services. Index of mobility elasticity of population towards gross domestic product is equal to 2 (Noniadze, 2014). This means that a $1 \%$ growth in GDP leads to a $2 \%$ growth in passenger traffic. As for air transport itself, in relation to Georgia, there is a positive correlation between GDP and passenger flow and it is equal to 0.92. Statistical data for the years 2015-2019 were used to calculate the correlation coefficient. The relationship between economic growth and civil aviation activity is complex and homogeneous, as particularly high correlation coefficients between airlines and GDP imply a strong linear relationship between the two variables.

According to Gegeshidze (2010) there are several problems with using GDP per capita as a measure of the economy:

- Its growth depends on the nominal value of the selected basket of goods according to the base year;

- It does not provide any relevant information on income distribution in the country;

- It does not take into account the negative external effects of environmental pollution by businesses. The cornerstone of the work of modern civil aviation is the reduction of harmful effects on the environment caused by the activities of industry;

- It does not record the positive externalities that can be caused by services such as education and health. For aviation as a science-capable field, education is of great importance because technological advancement contributes to the socio-economic efficiency of the field;

- It does not include information on the depreciation of goods already produced, or changes in value that could affect a change in living standards.

Economists use GDP as a macroeconomic indicator, but it is difficult to determine the exact extent of its impact, i.e. the exact distribution of income to the population. The Gini coefficient is used as a measure of the income and welfare inequality of the population, i.e. it best reflects the difference between rich and poor. Countries with market economies, at different stages of development, are at different levels of the social inequality index. Countries with highly developed economies have low rates of social inequality. According to the OECD (Organization of ecomomic co-operation and Development, 2020), the Scandinavian countries have the lowest Gini coefficient (Norway, Sweden, Finland, Denmark). Gini coefficient in Georgia is high compared to these countries. Along with economic growth, the Gini coefficient in Georgia is also decreasing. According to the Gini coefficient among the post-Soviet countries, Georgia ranks second after Russia. This means that the rate of social inequality observed in our country is high. Since the field of our research is aviation and the 
accessibility of the mentioned transport for the population, we can say that despite the growth of GDP in Georgia, due to the high rate of social inequality, a small part of our citizens have access to expensive services as air travel is.

Another macroeconomic indicator that affects the change in passenger volume is the change in the exchange rate. Georgia has a floating exchange rate regime

( National bank of Gerogia, 2020).

The floating exchange rate regime is characterized by sharp fluctuations, which have a special impact on price dynamics, both in the short and long term. The reason is the high level of dollarization in the country and the large share of imported goods in the consumer basket. A 1\% depreciation of the exchange rate leads to a $0.28 \%$ increase in the consumer price level. In the long run, prices become even more sensitive to falling rates, in particular, a $1 \%$ depreciation of the exchange rate leads to a $0.43 \%$ increase in prices (National statistica office of Gergia, 2021).

Consumer price index - an indicator that characterizes the level of inflation, measures the average change in prices and tariffs on the goods and services that the population acquires for their own consumption. The consumer price index is the only indicator used to calculate the level of inflation, i.e. the index determines the change in the overall level of consumer prices. Consumer price index in Georgia includes 12 commodity groups (306 consumer goods) according to the International Classifier (COICOP). The composition of the 2019 consumer basket has been updated. It is based on the consumption data defined by the system of national accounts and the system of internal surveys, which reflects the structure of domestic expenditures (National statistica office of Gergia, 2021). A large amount of USD is flowing out of Georgia for the payment of imported goods, which increases the demand for the currency and, consequently, the price. The list of commodities includes transport, which in its turn includes air travel (along with other modes of transport). Thus, it is interesting to consider the change in the consumer price index in the transport group and in particular in the context of air transport.

Despite the inflation rate, the price of air travel is declining compared to the same period last year (2020), paradoxically due to government bans caused by the new Covid-19 pandemic, and at the same time, negative expectations from the world population.

A high rate of inflation. Consumer spending of fixed-income citizens is growing even more in the conditions of high inflation. This reduces their mobility ratio and consequently their access to air transport.

The total number of employees in our country is 1 million 694 thousand citizens. The average salary of the employed population in Georgia is 1209 GEL. These figures significantly vary in different regions of the country. The population with the highest income lives in the capital, and the population with the lowest income lives in Racha-Lechkhumi. By the data of national data for 2016-2019, transport in the structure of internal expenses of Georgia makes up around $13 \%$ of the total expenses and amounts to $173 \mathrm{GEL}$ per month (National statistica office of Gergia, 2020).

According to the data of Eurostat published by the Lux- embourg Center for Cross-Cultural Data Research (2016$2019)$, in Europe, $13 \%$ of the consumer spending of the middle-income family, \$30-45 000, so as in Georgia, comes from transport and amounts to 487 euros per month (European statistical agency, Eurostat, 2020). The high level of inflation of the national currency reduces the transportation costs of citizens with fixed incomes. Using the Consumer Price Index Calculator (offered by Geostat) it is possible to calculate fixed amounts taking into account inflation. For example, the change in the consumer price index in January 2017 compared to 2016 amounted to $3.88 \%$. 1000 GEL in 2016, taking into account inflation, as of January 2017 is $1038 \mathrm{GEL}$ and 76 Tetri. 1500 GEL - 1558 GEL and 14 tetri, 2000 GEL - 2077 GEL and 52 tetri. The change in the consumer price index in January 2020 compared to January 2019 was $6.38 \%$. Taking into account 1000 GEL in January 2019, as of 2020, it is 1063 GEL and 83 Tetri. To determine the welfare of a country and for international comparison, world countries and international organizations represent GDP using the PPP (GDP purchasing power parity) method. PPP is an indicator of the purchasing power parity of a country's GDP. The strength of the US dollar varies from country to country, so the consumer price index, or what a single US dollar buys in a particular country, is more important than the official exchange rate. In general, the PPP method of GDP per capita is much more efficient at the international level and presents a much more accurate picture in the process of comparing the economic indicators of countries. It should be noted once again that the difference between exchange rates and prices is excluded in this method. The GDP of the countries per capita, using the PPP method, provides real information about the change in mobility of the population in conditions of high inflation (Gegeshidze, 2010).

The success of an airline in a market economy largely depends on the right pricing strategy. The whole difficulty of pricing lies in the fact that price is conjunctural category. It is substantially influenced by a complex of political, social, psychological, and economic factors. The demand, supply, usefulness, and quality of goods are of crucial importance.

The attitude of the supplier and the customer towards the price is opposite. The supplier wants to sell the goods at a high price, which is a prerequisite for the development of production, but at the same time it reduces the number of sales. Low price conditions are acceptable for consumers, which increases consumption but hinders the development of production. With marketing approaches, price, as one of the tools of influence from the supplier to the customer, is justified when it is attractive to the customer and profitable for the manufacturer.

The amount of profit should be considered to the extent that the airline not only secures payments to the state budget, financial institutions, and suppliers but also receives a certain amount of profit for extended reproduction. As already mentioned, many factors affect the price level, the economic factor is the most important among them, due to the scale of its impact on the price. Economic factors can be divided into two main groups:

Factors that bring the price closer to public spending and Factors that deviate the price from the value. In the first 
group of factors, the cost structure is in the foreground, while in the second case, the demand-supply structure should be distinguished. Airline ticket prices have dropped in Georgia over the last decade. There are many reasons for this, but above all, it is due to the increase in the number of airlines, including, from year to year, the increase in the market share of budget airlines, which ultimately creates the precondition for price competition (Noniadze, 2014).

Currency depreciation stimulates exports, tourism is an export sector, so the current inflationary processes have contributed to the development of tourism in Georgia. The exchange rate is an important factor for international visitors. They attach great importance to the cost of the dollar when deciding to travel to Georgia, which is reduced in the context of a strong dollar. This fact is stimulating for them and consequently leads to an increase in the number of tourists. More visitors mean more foreign currency in the country, and this will ultimately have a positive impact on both the country's economy as well as the operation of the transport system.
The factors discussed show that under the influence of recent exchange rate and price dynamics, Georgia as a tourist destination has become more competitive and cheaper for foreign visitors, which in its turn stimulates the growth of the number of visitors and revenue (USD) in the country.

\section{CONCLUSION:}

Thus, within the research component of the paper, the factors affecting aviation were structured according to the subjective and objective factors of direct and indirect impact. The increase in the number of air passengers is the result of the impact of many factors, but due to the scale of the impact, special attention was paid to the group of economic factors - the set of circumstances that are most correlated with the change in transport volume.

\section{REFERENCES:}

Dumbadze, N., Sukhitashvili, Y. and Noniadze, A. (2009) Civil Aviation Economy. Basic of planning and forecasting in Civil Aviation, Evaluation indicators of work in the aviation enterprise. Tbilisi, Bartoni. 140-141. (In Georgian).

Europe statistic agency (2019). Economy and finance. Prices, housing prices and statistics. Retrieved 10.03. 2021 https:// ec.europa.eu/eurostat/data/database

Gegeshidze, E. (2010). Dissertation. Gross Domestic Product and economy growth. 2010. Tbilisi state unievrsity.(In Georgian), retrivied. 10.03.2021. https://www.tsu.ge/data/file_db/library/PHD_Eka\%20Gegeshidze.pdf

National bank of Georgia (2021). Publication. Currency policy and reserve managment. Last view 1.04.2021 from: https:// www.nbg.gov.ge/index.php?m=521

National statistica office of Gergia 2020. Stastistical data of GDP. Retrieved 3.04.2021 from:https://www.geostat.ge/ka/modules/categories/23/mtliani-shida-produkti-mshp

Noniadze, N. (2021). Dissertation. Developing methodology, for acquiring markets of regional aviation, trough improvement of technical-economic decisions. National Parliamentary Library of Georgia. Retrieved 10.03.2021. http://217.147.235.82/ handle/1234/171824

Organisation for Economic Co-operation and Development (2020) OECD Income Distribution Database (IDD): Gini, poverty, income, Methods and Concepts. Last view 9.042021. from: https://www.oecd.org/social/income-distribution-database. htm

Socio-economic development strategy of Georgia. Development/deepening of international trade relation. Georgia (2020). Retrieved 1.04.2021 from: http://gov.ge/files/382_42949_233871_400-1.pdf 